\title{
Corticolous myxomycetes from Turkey
}

\author{
BRUCEING
}

ING, B. 2000: Corticolous myxomycetes from Turkey. - Karstenia 40: 63-64. Helsinki. ISSN 0453-3402.

Seventeen species of myxomycete were cultured from the bark of living trees collected in Turkey. Four species appear to be new records for Turkey.

Key words: Turkey, myxomycetes, corticoles.

Bruce Ing, Department of Biology, University College Chester, Parkgate Road, Chester CHI $4 B J$, U.K.

\section{Introduction}

During a botanical tour of SW Turkey in the spring of 1989 collections of bark from living trees were made by Patricia and the late Leonard Livermore. These were placed in moist chamber culture and the resulting sporocarps were harvested and identified. Four species additional to those recorded by Ergül and Dülger (2000), Härkönen (1988) and Härkönen and Uotila (1983) were noted and most of the records came from areas not previously investigated for myxomycetes. Records of myxomycetes from the eastern Mediterranean include those of Härkönen (1988), Härkönen and Uotila (1983) and Ergül and Dülger (2000) for Turkey, Ing and Zervakis (2000) for Greece, Ing and Ivancevic (2000) for Yugoslavia, Ing $(1987,2000)$ for Cyprus and Ramon (1968) and Binyamini $(1986,1987,1991)$ for Israel. The general aridity of the region does not result in a reduced myxomycete flora; on the contrary, the myxoflora recorded is not markedly different from that found in similar vegetation in the Mediterranean region in general (Lado 1994.) Material is preserved as microscope slides in Hb. B. Ing.

\section{Collecting sites}

1 - Ak Daglari is an extensive limestone mountain (3024 m) with cultivated land on the lower slopes above which is typical macchia, then well-developed forests of Pinus brutia Ten. giving way to stands of Cedrus libani L. and finally Juniperus excelsa Bieb.

2 - Ocakkhoy lies inland from the seaport of Fethiye at the head of a plain at $330 \mathrm{~m}$. The slopes above have phrygana vegetation which includes Quercus coccifera L. with scattered remnants of Pinus brutia forest.
3 - Dalyan has a sandy beach fringing the delta of the Dalaman River with planted Morus and Eucalyptus.

4 - Pamukkale (ancient Hierapolis) has trees planted around the ruins, including Acer negundo L. and Cupressus sempervirens L.

5 - Kalkan is a coastal resort with street tress and small groves of Olea europaea L.

6 - Xanthos is another important historic site, with degraded forest vegetation, mostly phrygana, including Ceratonia siliqua L.

7 - Denizli - Pamukkale, Salix scrub along the road.

\section{List of species}

Comatricha laxa Rostaf. - Site 1, on Juniperus oxycedrus L. A widespread species on wood, less common on bark. Not uncommon in the Mediterranean region.

C. nigra (Pers.) Schröt. -1, on J. oxycedrus. Cosmopolitan and very common on wood, less so on bark but frequent on that of conifers.

Didymium minus (List.) Morg. - 1, on Cercis siliquastrum L. A litter species which rarely appears in bark cultures unless they are kept for some months, as in this case. Cosmopolitan and frequent in the western Mediterranean region but otherwise only known from Greece and Israel in the east.

Echinostelium apitectum Whitney (incl. E. vanderpoelii Nann.-Bremek., Mitchell, Chopra \& Lakhanpal.) - 1, on Populus sp.; 2, on Quercus ithaburensis Decne. ssp. macrolepis (Kotschy) Hedge $\&$ Yalt.; 5, on Olea europaea L. Recorded on a few occasions in the western Mediterranean and from Cyprus, Greece and Israel; new to Turkey. 
E. brooksii Whitney - 2, on Pinus brutia. Widespread and common in Europe on exposed trees. Recorded from Greece and Cyprus; new to Turkey. E. coelocephalum Brooks \& Keller - 7, on Salix sp. A rare species with few European records.

E. colliculosum Whitney \& Keller -4, on Acer negundo; 6 , on Ceratonia siliqua. Common in north America and Europe but not often recorded from the eastern Mediterranean, although known from Greece and Cyprus.

E. corynophorum Whitney - 3, on Eucalyptus sp. Frequent in Europe and recorded from Greece and Cyprus.

Enerthenema papillatum (Pers.) Rostaf. -1, on $J$. oxycedrus. Cosmopolitan and common on wood and bark of confers and hardwoods, especially Quercus spp.

Licea kleistobolus G.W.Martin - 2, on Q. ithaburensis. Widespread and often abundant.

Paradiacheopsis fimbriata (G.List. \& Cran) Hertel $-\mathbf{1}$, on $J$. oxycedrus. Widespread and common in Europe, especially on acid-barked trees or those affected by atmospheric pollution.

P. solitaria (Nann.-Bremek.) Nann.-Bremek. -4, on $A$. negundo. Widespread and common in Europe, especially in older, less managed forests. Less common in the eastern Mediterranean region but recorded from Greece and

Yugoslavia; new to Turkey.

Perichaena chrysosperma (Currey) List. - 2, on P. brutia; 3, on Morus sp. Cosmopolitan, usually on bark but occasionally on fallen wood or leaf litter.

Physarum auriscalpium Cooke-2, on P. brutia. [Hb. Ing 89001] Widespread in temperate regions but often confused with $P$. decipiens Curtis and not always separated in the literature on the Mediterranean. The current species has been recorded from Greece and Yugoslavia while $P$. decipiens, perhaps in a broad concept, is listed from Turkey.

P. pusillum (Berk.\& Curt.) G.List. -4, on Cupressus sempervirens. Cosmopolitan, on bark and, characteristically, on many forms of grass litter. Widespread in the western Mediterranean and recorded from Greece, Israel, and Yugoslavia.

Stemonitopsis subcaespitosa (Peck) Nann.Bremek. - 1, on Juniperus excelsa; 4, on A. negundo. Widespread in temperate regions on wood and bark but never common and often confused with other species of Stemonitopsis and
Comatricha. Rare in the western Mediterranean and known from Greece; new to Turkey.

Trichia contorta (Ditm.) Rostaf. - 3, on Morus $\mathrm{sp}$. Widespread in temperate regions, usually on wood and rare on bark. The species collected are typical of the vegetation types visited and similar to those found in comparable areas of Greece (Ing \& Zervakis 2000.) However more collecting, especially in the main mycological collecting seasons of late autumn, and in more extensive areas of forest, should greatly increase the Turkish list. The areas of damper woodland along the Black Sea are relatively unknown mycologically and should be investigated in the near future. The use of moist chamber culture of bark from living trees provides a rapid snapshot of the myxoflora and, if the cultures are allowed to continue for three months, also allows the germination and development of non-corticolous species whose spores were trapped on the bark prior to collection.

Acknowledgements: This work would not have been possible had not Pat and Len Livermore collected the bark and transported it back to Britain for study and warm thanks are extended.

\section{References}

Binyamini, N. 1986: Myxomycetes from Israel I. Nova Hedwigia 42: 379-386.

Binyamini, N. 1987: Myxomycetes from Israel II. Nova Hedwigia 44: 351-364.

Binyamini, N. 1991: Myxomycetes from Israel III. Trans. Mycol. Soc. Japan 32: 485-493.

Ergül, C. \& Dülger, B. 2000: Myxomycetes of Turkey. Karstenia 40: 00-00.

Härkönen, M. 1988: Some additions to the knowledge of Turkish myxomycetes. - Karstenia 27: 1-7.

Härkönen, M. \& Uotila, P. 1983: Turkish myxomycetes developed in moist chamber culture. - Karstenia 23: 1-9.

Ing, B. 1987: Corticolous myxomycetes from Cyprus. Mycotaxon 30: 195.

Ing, B. 2000: Interesting myxomycete records from Asia. - Mycotaxon (in press.)

Ing, B. \& Ivancevic, B. 2000: A checklist of myxomycetes from former Yugoslavia. - Stapfia (in press).

Ing, B. \& Zervakis, G. 2000: A checklist of myxomycetes from Greece. - Mycotaxon (in press).

Lado, C. 1994: A checklist of myxomycetes of the Mediterranean countries. - Mycotaxon 52: 117-185.

Ramon, E. 1966: Myxomycetes of Israel. - Israel J. Bot.17: 207-211. 